\title{
WORKMAN'S COMPENSATION:-THE DUAL PURPOSE RULE AND THE EMPLOYEE-PASSENGER
}

$\mathrm{T}$ TITFALLS inherent in applying a venerated legal formula to a Western Fireproofing Co. ${ }^{1}$ In that case, the plaintiff, a part-time clerk, and her husband, the supervisor of a mobile roofing crew, were employed by the same employer. It was her practice to accompany her husband from job to job. Having completed one job, they were traveling in their employer's vehicle, which the husband was driving, to Springfield, Missouri, where he was to deliver roofing materials. They planned to travel on to their permanent home, near Springfield, for Christmas, after the materials were delivered. There they were to await their employer's instructions, during which time the plaintiff intended to complete certain company reports that she was carrying. While engaged in this mixed purpose journey, they were involved in an accident in which the plaintiff was injured. Significantly, the accident occurred on the route that her husband was required to travel on his business mission. Concededly, then, he was acting "in the course of his employment"2 at the time of the accident and presumably would have been compensated had he been injured. But the question the court

\footnotetext{
${ }^{1} 326$ S.W.2d 344 (Mo. App. 1959).

2 Workman's compensation acts generally require that an injury, to be compensable, must be one "arising out of and in the "course of employment." The following is a typical judicial interpretation of this phrase: An injury 'arises 'out of' the employment when there is a causal connection between the conditions under which the work is required to be performed and the resulting injury; and ... an injury ... arises in the course of' employment when it occurs within the period of his employment, at a place where he may reasonably be, and while he is reasonably fulfilling the duties of his employment or engaged in doing something incidental thereto." Spradling v. International Shoe Co., 364 Mo. $938,944,270$ S.W.2d 28, 30 (1954), quoting Wahlig v. Krenning-Schlapp Grocer Co. 325 Mo. 677, 68 I, 29 S.W.2d I28, 130 (1930).

The plaintiff's husband was probably "in the course of employment" uuder either of two theories. In accordance with the Marks 0 . Gray test, inasmuch as the business purpose would have to be performed by someone, sometime, the husband's business purpose made the trip a business journey within the course of employment, regardless of whether it coincided with, or was consolidated with, the private purpose of the journey. Second, in situations such as the present case where the same route is covered to reach both the business and personal objectives, that portion of the trip leading to the business mission may be segregated and at least that part of the journey called a business trip. In connection with the latter theory, see Kaplan v. Alpha Epsilon Phi Sorority, 230 Minn. 547, 42 N.W.2d 342 (1950).
} 
had to decide was whether the plaintiff's injury arose from the course of her employment. The Missouri Court of Appeals affirmed the state industrial commission's judgment for the defendant. In so doing, the court applied the familiar dual purpose test formulated by $\mathrm{Mr}$. Justice Cardozo in Marks v. Gray: ${ }^{3}$

To establish liability, the inference must be permissible that the trip would have been made though the private errand had been cancelled ... . The test in brief is this: If the work of the employee creates a necessity for travel, he is in the course of his employment, though he is serving at the same time some purpose of his own .... If, however, the work has had no part in creating the necessity for travel, if the journey would have gone forward though the business errand had been dropped, and would have been canceled upon failure of the private purpose, though the business errand was undone, the travel is then personal, and personal the risk. ${ }^{4}$

The Court of Appeals apparently regarded the plaintiff's journey to Springfield, and from there to her home, as a unity. Irrespective of the fact that it was her husband's business mission that brought them to the place of the accident, her trip would have been abandoned if her personal purpose, the journey home, had been canceled. The trip and the risk, the court reasoned, were thus personal, and she was not acting in the course of her employment.

The Barton case raises the novel question whether a husband's employment mission can bring his employee-wife within the scope of her employment, if she is traveling with him in a vehicle owned by their employer. Although there is no reported decision resolving this issue, the case that is closest to Barton on the facts implies, without deciding, that the husband's business mission might bring his wife within the course of her employment. ${ }^{5}$ In the more common situations where one

\footnotetext{
${ }^{3} 251$ N.Y. 90, 167 N.E. 181. The Marks \%. Gray test has received widespread approval of both courts and commentators. At least twenty-six states and the federal courts have applied Cardozo's formula. Professor Arthur Larson, commenting on the wide application of the rule, says it is "a lucid . . . formula which, when rightly understood and applied, has never yet been improved upon." I LARSON, WORKMEN's COMPENSATION 241 ( 1952 ).

25 I N.Y. at 93,167 N.E. at 183 .

${ }^{5}$ In Mulligan v. Oakes, 128 Conn. 488, 23 A.2d 870 (1942), the husband was a butler-chauffeur and his wife a cook for the same employer. The couple took Thursday afternoon off and used their employer's automobile to visit friends. The husband then mailed a package and several letters at the employer's request. The wife was injured in a collision while returning to the employer's home. It was held that her injury did not arise in the course of her employment because there was no causal connection between the injury and the employment. The court went on to say that "even if the [wife] ... could claim any benefit from the fact that [the husband],... on the
} 
employee is a passenger in a vehicle driven by another employee, who is on a business mission, the dual purpose rule apparently requires that the employees be treated as separate entities. ${ }^{6}$ Thus, the business purpose of the driver will not bring the employee-passenger within the scope of the workman's compensation act. Therefore, if the plaintiff in the Barton case is treated as the usual co-worker, Marks v. Gray was correctly applied.?

The court, however, disregarded certain significant facts that indicate that the plaintiff was something more than a mere co-worker. For example, recovery might have been allowed on the theory that the plaintiff's practice of riding from job to job with her husband in their employer's vehicle had become a custom that brought her within the course of her employment. Furthermore, the reason for the plaintiff's exposure to the risks inherent in the use of the employer's truck was not merely attributable to the behaviou of a dutiful wife. Her employment, apparently secured because she traveled with her husband, required that she move from job to job and be available to discharge her duties as clerk. ${ }^{8}$ It is recognized that payment of travel expenses by the employer can extend workman's compensation coverage to employees traveling to and from work. ${ }^{9}$ But the plaintiff, unlike other employees, was not

[employer's] . . . request, delivered a package and mailed some letters, this was too incidental a matter materially to change the nature of the trip they were making." Id. at 492,23 A.2d at 872 . Had the Marks $v$. Gray test been applied in this case, it would seem that the husband's business errand would have changed the trip into a business journey and the question in the Barton case would have been squarely presented.

- For example, in Travelers Ins. Co. v. Forson, 268 S.W.2d 219 (Tex. Civ. App. 1954), though the court admitted that transportation of the employer's water can to the employment premises each morning by employees on their way to work in a private vehicle might have been sufficient to establish a business mission, it went on to say that, even so, it was performed by the driver and not by the passenger-employee who was killed in the collision. Hence, the driver's business mission left unaffected the employment status of the passenger. The same tendency to treat a rider independently from the driver-employee who is on a business errand, is indicated by two other cases: Callahan v. State of New York, 201 Misc. 378, ro7 N.Y.S.2d 319 (195I); Bozant v. Federal Underwriters Exch., I59 S.W.2d 973 (Tex. Civ. App. 1942).

${ }^{7}$ Because the plaintiff was on her way home does not preclude application of the dual-purpose rule. Whether a trip becomes an exception to the usual rule excluding off-premise going and coming journeys is determined by the same principles that apply to out-of-town trips under Marks $v$. Gray. See I LARsoN, op. cit. supra note $3, \S$ I 8.21.

${ }^{8}$ Presumably, a person willing to perform such services would be difficult to find, considering the part-time nature of the employment and the frequent changes of job location.

${ }^{\circ}$ Whether a worker is within the course of his employment if he is compensated for travel time or travel expense, depends on the relative importance of the travel as a part of the service performed. For example, when an employer paid overtime wages to 
reimbursed for her travel expenses, and it might thus be argued that she was not covered by the workman's compensation act. However, more cogent analysis indicates that the fact that her employer did not pay her travel expenses did not operate to remove her from the act's coverage. Perhaps she was not given travel expenses because she was only a part-time employee. The more likely explanation, though, is that her employer expected her husband to arrange for her transportation. Therefore, it was not surprising to find her riding with her husband, even when he drove their employer's vehicle. The convenience of this arrangement caused the practice to become a custom. This was not merely an employer-extended courtesy. ${ }^{10}$ Although the defendant contended otherwise, the possibility that the plaintiff might have found

roofing employees at regular rates as compensation for travel time, leaving them frec to arrange their own transportation to and from work, injuries and death resulting when the auto of one employee, used by all under a common understanding that expenses would be shared, was struck by a locomotive during a journey from work to home, were compensable. The court said that it could be inferred that the employer had agreed that the employment relationship continue throughout the period of transportation. Kobe v. Industrial Acc. Comm'n, 35 Cal. 2d 33, 215 P.2d 736 (1950). An example of compensation for travel expense is illustrated by Croessman v. R.J. Moran \& Sons, 4 App. Div. zd 712, 163 N.Y.S.zd 546 (1957). An employer, in order to get employees to work on a job outside a city, agreed with the union to pay five cents per mile traveling expense plus the regular hourly rate from the city limits to the job site and return. The court held that an employee killed while so traveling was in the course of his employment and that his death was compensable.

${ }_{10}$ "[W] here an employer, without any agreement as to transportation, conveys his employees to or from his place of work merely as an act of courtesy, an accident occurring during the journey is not covered [by the Compensation Act] ...." Watson v. Grimm, 200 Md. 46r, 470, 90 A.2d 180, 185 (1952). Apparently, "courtesy" is construed to mean that the incident occurs infrequently or in isolated cases. Thus, for example, where an employer himself went around picking up employees in order to resume work after a rainstorm, the transportation was not within the course of employment. Pierdiluca v. Benedetto, 2 Io App. Div. 441, 206 N.Y.S. 358 (1924). However, where employees rode the employer's garbage truck to and from town every day, and the employer drove out of his way to let the employees off downtown after work, for their convenience, it was specifically held that this was not a "courtesy" because the trip was made two or three times a week. Watson v. Grimm, suppra. Thus, by custom and usage, travel in the employer's vehicle and other acts, though not directly a part of the employment activities, may be considered as within the course of employment. See also, Conley v. Meyers, 304 S.W.2d 9 (Mo. 1957).

Correspondingly, when there is no evidence that the employer's trnck was used with the consent, or even the lnowledge, of the employer, to drive some employees to work, or that there was any custom of using it to transport the workers, it was held that they were not acting within the course of their employment. Parisi v. Langston, $285 \mathrm{App}$. Div. 483,138 N.Y.S.2d I 78 (1955).

${ }^{11}$ Even if the employee did not have to avail himself of the means of transportation furnished by the employer, once the employee does so, he is considered as being within 
other transportation is immaterial. ${ }^{11}$ The risks inherent in traveling in the employer's truck became common to both the plaintiff and her husband. ${ }^{12}$ The dangers of improper vehicle maintenance, or of towing heavy equipment, for example, constituted risks within the control of the employer, ${ }^{13}$ and thus became an incident of the plaintiff's employment.

The plaintiff might also have been brought within the coverage of the workman's compensation act on the theory that, when part of the employee's work was performed at home, travel to and from the employer's premises became a part of the employment risk. ${ }^{14}$ The plaintiff performed many of her duties wherever she and her husband lived while on the job. ${ }^{15}$ The "home" was thus the situs of her employment. Inasmuch as she resided in one place only so long as that job lasted, no

the scope of his employment. Pearson v. Aluminum Co., 23 Wash. 2d 403, I6I P.2d I 69 (1945).

${ }^{12}$ The employer's truck, the plaintiff, and her husband moved forward as a single unit in time and space. Any inherent risks were shared commonly and may be considered as an extension of the employer's premises and the dangers of employment.

${ }^{13}$ "When a workman is . . . injured, while being transported in a vehicle furnished by his employer, as an incident of the employment, he is within 'the course of his employment,' as contemplated by the [Workman's Compensation] Act. In other words, when the vehicle is supplied by the employer for the mutual benefit of himself and the workman to facilitate the progress of the work, the employment begins when the workman enters the vehicle and ends when he leaves it on the termination of his labor. This exception to the rule [nonliability for injuries to employees going to or coming from work] may arise as a result of custom or contract, express or implied. It may be implied from the nature and circumstances of the employment and the custom of the employer to furnish transportation." Venho v. Ostrander Ry. and Timber Co., I 85 Wash. 138, 139-40, 52 P.2d 1267, 1268 (1936). This case was cited with approval in Pearson v. Aluminum Co. 23 Wash. $2 \mathrm{~d}_{403} 412-13,161$ P.2d 169, 173 (1945). The basic notion here is that coverage is extended because of the extension of the risks under the employer's control. "Where the driver of the vehicle is furnished by the employer, the employee's case is stronger because then the employer's agent has control over the acts and movements of the employee." Watson v. Grimm, $200 \mathrm{Md}$. 46I, 472, 90 A.2d I 80, I 86 (1952).

It See, for example, Allen's Dairy Prod. Co. v. Whittington's Dependents, 230 Miss. 285,92 So. 2 d 842 (1957), where a wholesale milk deliveryman was killed on the way home from work. He customarily prepared daily reports at home with the help of his wife, and this activity was known to the employer. It was held that he was in the course of employment even though on the day of the accident he had sent the information for the reports home while he went on a personal errand. See also, Tiernan v. Potter, 28 I App. Div. 787 , I 8 N.Y.S.2d 43 I (1953), where a nurse-secretary was compensated for an injury sustained in an accident that occurred on the way home from work because it appeared that, at the employer's direction, she rendered certain services at her home in the evening, that the employer furnished her with supplies and that she was carrying stenographic notes for transcription at the time of the accident.

${ }^{16}$ Brief for Appellant, p. 13. 
real problem is presented by viewing their "permanent" home, where they intended to spend Christmas, as part of their usual living pattern. Because the plaintiff usually worked after normal business hours, and at the time of the accident intended to complete the reports she was carrying at home, the journey might properly be considered as within the course of her employment, and the risks of the journey would be incidental to her employment.

Thus, although the Marks v. Gray dual purpose test is a convenient, flexible formula, the dangers inherent in the application of such tests have prompted the common-sense admonition that "every case involving the quoted phrase [arising out of and in the course of employment] should be decided on its own particular facts and not by formula."10 The complex employment arrangements engendered by the growing number of traveling employees make precise analysis of each factual situation particularly crucial. The Barton case illustrates the courts' tendency to consider only the obvious facts of a case and to seize upon and restrict themselves to recognized formulas, notwithstanding resulting inequities. The Marks v. Gray formula is to be highly regarded, but its appeal must not obscure the fact that the burgeoning variety of new and unusual factual situations in workman's compensation cases make its indiscriminant application unjust.

\footnotetext{
${ }^{16}$ Barton v. Western Fireproofing Co., 326 S.W.2d 344, 348 (Mo. App. I959); Heaton v. Ferrell, 325 S.W.2d 800, 804 (Mo. 1959); Dehoney v. 'B-W Brake Co., 271 S.W.2d 565, 567 (Mo. 1954); Foster v. Aines Farms Dairy Co., 263 S.W.2d 421, 423 (Mo. 1953); Leilich v. Chevrolet Motor Co., 328 Mo. 112, 122, 40 S.W.2d 6or, 605 , (1931). In two cases, Spradling v. International Shoe Co., 364 Mo. 938, 270 S.W.2d 28 (1954), and Lunn v. Columbian Steel Tank Co., 364 Mo. 124r, 275 S.W.2d 298 (1955), the Supreme Court of Missouri refused to apply any formula in reaching its decisions. However, it is believed that the same results might have been reached by applying correctly recognized rules of workman's compensation. The Spradling and Lunn cases are noted by, and receive favorable comment from, Roscoe Pound in 15 NACCA L.J. 75 (1955), and I6 id. II I (1955). There is little reason to believe that courts will cease using heretofore widely accepted workman's compensation formulas in favor of some other nonformula approach such as the Missouri court has taken in the two mentioned cases.
} 